\title{
Microteaching Guided by an Expert Secondary English Teacher: The Effect on Pre-Service English Teachers' Pedagogical Content Knowledge
}

\author{
Siti Aimah ${ }^{1}$, Dwi Rukmini ${ }^{2}$, Mursid Saleh ${ }^{3}$, Dwi Anggani Linggar Bharati ${ }^{4}$
}

\footnotetext{
1 Semarang State University, Post Graduate Program, Jl. Kelud Utara III, Semarang, Jawa Tengah, ID-50233, Indonesia, siti.aimah@unimus.ac.id

2 Semarang State University, English Education Program, Sekaran, Gunung Pati, Semarang, Jawa Tengah, ID-50229, Indonesia, wiwidwirukmini@yahoo.com

3 Semarang State University, English Education Program, Sekaran, Gunung Pati, Semarang, Jawa Tengah, ID-50229, Indonesia,mursids@hotmail.com

4 Semarang State University, English Education Program, Sekaran, Gunung Pati, Semarang, Jawa Tengah, ID-50229, Indonesia, dwi_anggani@yahoo.com
}

\begin{abstract}
This study aims to determine the effect of microteaching guided by an expert secondary English teacher on pre-service English teachers PCK, focusing on the changes before and after expert-guided microteaching. The equivalent time-series design involves a single-group, repeatedly assessed, with the treatment introduced between the measurements. Expert-guided microteaching significantly affects pre-service English teachers' PCK and triggers them to know what to teach and how to teach for students.
\end{abstract}

Keywords: changes, effect, expert teacher, microteaching, pedagogical content knowledge, pre-service English teachers.

\section{Introduction}

Student teaching internship is one of the basic requirements for pre-service English teachers in preparation of knowledgeable, reflective practitioners and emerging leaders that conduct themselves ethically and professionally. They are offered the opportunity to 
develop their multiple teaching skills such as designing lesson plans, formulating teaching goals, speaking in front of peers, posing questions, and the application of evaluation techniques in a microteaching class (Kilic, 2010). Unfortunately, most of them have been unable to meet the requirements of teaching practice (Based on teachers' evaluation conveyed to the head of the study program of the English Education Department on September $7^{\text {th }}$, 2018). They are unable to design a lesson plan, carry out instructional processes, manage time and classroom, including mastering the subject matter and explaining it in an understandable manner.

First, the different perception of the students and lecturers in designing a lesson plan is often confusing. Adi (2015) reported that pre-service teachers usually formulate two models of lesson plans, which are designed differently to cover the activities of learning. Similarly, Ghanaguru, Nair, \& Yong (2013) stated that they encounter certain problems concerning creating an effective lesson plan that offers learning experiences to students, allocate the appropriate time, and its execution in the classroom. Second, the issues commonly encountered lies in the management of time and classroom. For instance, it was observed that pre-service English teachers usually had ample time left after they had taught the students (Bertus, Matsum, \& Syahrudin, 2018; Gorgoretti \& Pilli, 2012; Tokmak \& Karakus, 2011). Third, their mastery of teaching materials is also another problem usually faced during teaching internship, in addition, the inability to explain the subject matter also aggravates this condition (Afrilianti, Ulfah, \& Achmadi, 2016).

Consequently, all these issues are basically related to a lack of pedagogical content knowledge (PCK). It comprises content and pedagogical knowledge, which is unique to pre-service English teachers and is based on how they implement the teaching and learning process. Based on the importance of PCK in boosting competence, there is a need to resolve the problems mentioned above. Initially, microteaching, which offers them the opportunities to develop these qualities, was formerly guided by the lecturer. However, it is presently supervised by an expert teacher, conversely, this is aimed at bridging the gap between these two in assisting pre-service English teachers. Besides, expert-guided microteaching also aims to provide constructive feedback, guidance, and exemplary lessons that systematically conduct instructional practices.

In addition, numerous studies have been carried out on microteaching, although their main focus is on teaching performance (Bahjat, 2016; Bakir, 2014; Baştürk, 2016; Cobilla, 2014; Copeland, 1975; Donnelly \& Fitzmaurice, 2011; Elias, 2018; Gödek, 2016; Kamimura \& Takizawa, n.d; Onwuagboke, Osuala, \& Nzeako, 2017; Punia, Miglani, \& Singh, 2016; Saban \& Çoklar, 2013; Shah \& Masrur, 2011; Şen, 2010; Simbo, 1989). Unfortunately, studies that focus on PCK are still lacking irrespective of the fact that it is extremely important for pre-service teachers because it aids them to effectively carry out the instructional processes. On the contrary, PCK is commonly developed during microteaching (MLS) (Birel \& Çakiroğlu, 2018; Cavin, 2007; Suryani, Rukmini, Bharati, \& Hartono, 2017; Zhou, Xu, \& Martinovic, 2017). 
The importance of PCK has been deliberated on in several studies (Ghazi, Shahzada, Shah, \& Shauib, 2013; Großschedl, Welter, \& Harms, 2018; Kourieos, 2014; Yüksel, 2014). It aids pre-service teachers to effectively convey the teaching process (Suhirman, 2018). On the contrary, lack of knowledge, causes them to be unable to help students counter certain learning problems.

Therefore, this study explores the importance of PCK, facilitated by expert-guided microteaching. Pre-service English teachers need to understand and effectively carry out teaching and learning processes. This study focuses on the changes before and after impacting PCK through expert-guided microteaching.

\section{Literature review}

\section{Teacher Knowledge-Base}

In this context, a teacher's knowledge-base is conceived as all potentially relevant skills required to carry out instructional processes (Fernandez, 2014; Johnson, 2009), however, for the past 10 years, it has been related to the role of content in teaching (Shulman, 1986). In practice, competency is not only characterized by teaching content instead there is a need for the teachers to possess adequate knowledge of the subject matter to provide the students with sufficient information (Ghazi et al., 2013; Spear-Swerling, Brucker, \& Alfano, 2005; Yang, Liu, \& Gardella, 2018).

Shulman, 1987 carried out a study focused on the role of content and the teacher's ability to carry out instructional processes, including teaching certain topics. In other words, it was based on content and pedagogical knowledge. Similarly, Mishra \& Koehler (2006) reported that the fundamental basis of teaching requires teachers to possess an adequate understanding of the students' learning process, though, and subject matter, which is all encompassed in content knowledge (CK) and pedagogical knowledge (PK). They are jointly referred to as pedagogical content knowledge (PCK) and are considered as the primary component that affects students' achievement (Baker \& Chick, 2006; Bertram, \& Christiansen, 2012; Carlsen, 1999; Diamond, Grossman, Fernandez, 2014; Liakopoulou, 2011).

Therefore PCK is a basic requirement in the teaching profession, in addition, preservice English teachers need to understand the content as well as possess pedagogical knowledge. However, it is expected of them to select appropriate learning approach, strategy, method, and media in order to create an effective teaching environment.

\section{Pedagogical Knowledge (PK)}

The study carried out by Shulman 1987 is centered on pedagogical knowledge (PK). It involves an understanding of the teaching processes and preparation, classroom management, formulating lesson plans, methods and strategies, students' characteristics, 
as well as designing learning evaluation (Aimah, Ifadah, \& Bharati, 2017; Aksu, Metin, \& Konyalioğlu, 2014; Mishra \& Koehler, 2006). This is consistent with the study carried out by Gess-Newsome (1999), which stated that PK is based on the organization and management of teaching models and strategies, including communication and discourse in the classroom.

Furthermore, it aids teachers during decision-making and to carry out instructional processes in the classroom. It encompasses an understanding of the students' learning process, lesson plan, assessment, and classroom management. Teachers that possess indepth knowledge of PK tend to understand their students, as well as encourage them to learn (Aksu et al., 2014). Therefore, to strengthen this quality, teachers need to understand cognitive, social, and developmental theories of learning and apply and integrate them in the classroom (Mishra \& Koehler, 2006). Meanwhile, Hudson, English, Dawes, King, \& Baker (2015) reported that PK is used to facilitate effective teaching practices. Gurney (2007) further stated that certain factors, such as teachers' knowledge base, learning activities, assessment, effective feedback, the interaction between the teacher and students, as well as creating a conducive learning environment, which is embedded in pedagogical knowledge, need to be considered in order to realize a competent teaching process.

\section{Content Knowledge (CK)}

Content knowledge is regarded as a core element in the development of the teaching profession (Ballmart \& Kunter, 2006). According to Ball, Thames, \& Phelps (2008), it involves knowledge of the subject matter and its structures, therefore, there is a need for teachers to understand the subject matter, they are about to teach the students (Aksu et al., 2014; Ball et al., 2008; Harris, Mishra, \& Koehler, 2009; Kleickmann, Richter, Kunter, Elsner, Besser, Krauss, \& Baumert, 2013; Mishra \& Koehler, 2006). Conversely, the inability to properly understand the content causes them to be unable to aid the students in learning the material (Ball et al., 2008; Ghazi et al., 2013).

However, pre-service English teachers need to be properly informed about the content as well as make it understandable when teaching the students. It is absolutely important for them to be able to apply the knowledge that they have mastered in the context of teaching. Therefore, based on this regard, pre-service English teachers need to understand that the subject matter taught in the classroom is completely different from that they were taught in college. Accordingly, they have to simplify the material and adjust it to the students' level. They also need to cite some analogies or examples in order to aid them in understanding their explanation (Shulman, 1986).

\section{Pedagogical Content Knowledge (PCK)}

According to Shulman (1987), Pedagogical content knowledge (PCK) is a basic requirement for teaching. It is closely related to understanding concepts, pedagogical techniques, and students' prior knowledge (Gess-Newsome, 1999). Therefore, PCK plays an important 
role in developing teachers' expertise (Faisal, 2015). It influences the pattern of teaching as well as encourages the students to understand the learning process.

It was reported that initially, CK was separated from $\mathrm{PK}$, although presently, both have been integrated into the teaching and learning processes. Teachers need to transform the subject matter using appropriate examples to simplify it for the students (Driel, Verloop, \& Vos, 1998; Faisal, 2015; Geddis, 1993). The essence of this function is to determine the success of the teaching process. However, Jang, Guan, \& Hseieh (2009) reported that this process's success lies in the teachers' mastery of the subject matter and their understanding of students' prior knowledge and learning problems. Therefore, in carrying out the instructional processes, students need to be actively engaged in activities that optimally explore their abilities.

Therefore, the importance of PCK aids pre-service English teachers to create a meaningful learning environment. However, they need to possess knowledge of the content (subject matter) to be taught, clearly explain it, make it interesting, offer regular feedback, and help resolve their learning problems (Olson \& Moore, \& Jang et al., 2009).

The importance of PCK in teacher education programs has been highlighted in numerous studies (Reynolds, 1992; Tuan, Chang, Lee, Wang, \& Cheng, 2000). In accordance with the study, carried out by Jang et al.'s (2009), four main categories of PCK which encompasses of Subject Matter Knowledge (SMK), Instructional Representation \& Strategies (IRS), Instructional Objective \& Context (IOC), and Knowledge of Students' Understanding (KSU) were designed and developed. SMK refers to the extent of the teacher's understanding of the subject matter taught. IRS is defined as the teachers' ability to select and use analogies, examples, including their explanation, and appropriate teaching strategies. IOC encompasses the teaching process, learning atmosphere, teacher's attitudes, and classroom management. Subsequently, KSU refers to the teacher's ability to evaluate students' understanding either at the beginning, in the middle, or at the end of the teaching and learning process.

\section{The Involvement of an Expert Secondary English Teacher in Microteaching Class}

The ability of teachers to manage the classroom needs to be considered. It is believed that classroom management is regarded as a core component of effective teaching performance and teachers' expertise development (Berger, Girardet, Vaudroz, \& Crahay, 2018; Wolff, van den Bogert, Jarodzka, \& Boshuizen, 2014). It does not only involve the ability to maintain silence during classes, however, it deals with students' cognitive outcomes and behavioral engagement (Jang et al., 2010; Reeve, 2009; Weinert \& Helmke, 1995; Wolff et al., 2014).

Expert teachers possess at least ten years of teaching experience, and their ability to manage the classroom is recognized by peers and school administrators (Berger et al., 2018; Berliner, 2001; Chi, 2006). Further, Wolff et al. (2014) reported that they usually focus on learning activities carried out in the classroom as well as their ability to encourage 
the students to study. Therefore, teachers play an important role in actively engaging the students as well as focus on their understanding, which is boosted by the teaching experiences gained over the years (Copeland, Birmingham, DeMeulle, D'Emidio-Caston, \& Natal, 1994; Livingstone \& Borko, 1989; Tsui, 2009). This also enables them to have a better understanding of classroom management by foreseeing issues related to learning, resolving such problems, as well as adapting to certain practices (Carter et al., 1988; Schempp, Tan, Manross, \& Fincher, 1998; Wolff et al., 2014).

The supervision of microteaching by lecturers in universities usually focuses on pre-service English teachers' teaching performance and weaknesses. However, the feedback based on PCK and those delivered by peers slightly contributes to the refinement of their performance. Therefore, their performances are similar to those in previous studies. It was also discovered that the guidance and exemplary lessons put forward by pre-service English teachers often do not exist in the microteaching class. Consequently, they do not clearly understand ways of simplifying the subject matter in order to make it easier for the students to assimilate. Besides, designing a lesson plan and executing it in the instructional practice often makes them confused. Therefore, as an evaluation, an expert teacher is required in a microteaching class.

Microteaching, guided by an expert teacher, focuses on teaching peers in the classroom within a limited time (Allen, 1967; Fernandez, 2010). It comprises a lesson plan, teaching, and feedback, subsequently re-conducted (Banga, 2014; Peker, 2009). This has a great influence on the teaching performance of pre-service teachers (Cheng, 2017). The expert teacher is responsible for lesson preparation and correction of exercises, which is included in PCK. This is consistent with the study carried out by Gün (2014), which stated that the teachers activities in the class, their thinking before and during teaching, is regarded as a crucial and complex aspect of teaching.

In microteaching class, the expert teacher is assigned to monitor the entire points of pre-service English teachers' performance, including PCK. The guidance and exemplary lessons shared are expected to serve as good models when implementing instructional practices.

\section{Method}

A quasi-experimental design, associated with an equivalent time-series design, was used to carry out this study due to a class's availability in the microteaching class. Therefore, multiple observations were taken between each intervention.

\section{Participants}

A total number of eleven pre-service English teachers consisting of 1 male and 10 female, aged 21-21 taking the class of microteaching from the English Education 
Department, voluntarily participated in this research. The participants were expected to provide useful information while answering the research question due to their willingness to be involved in the research. Accordingly, convenience sampling was used.

All participants were taught in a microteaching environment by designing an individual lesson plan, discussing and simulating the lesson plan in the instructional process, providing constructive feedback to the performance, re-designing the lesson plan, re-teaching it, and re-providing feedback. The expert teacher assisted the preservice English teachers from planning the lesson to evaluating students' understanding by sharing exemplary lessons and providing guidance on the right strategies needed to conduct the instructional process.

\section{Data Collection}

The data were collected through observation, which was used to assess the teachers' PCK before, during, and after the expert-guided microteaching process. Furthermore, the observation process was adapted and modified using the Jang et al. (2009) theory. The study consists of three raters, one is an expert secondary English teacher teaching the microteaching class, while the other two are observation lecturers. The raters were mandated to assign scores ranging from 1 (very poor), 2 (poor), 3 (good), to 4 (very good) to the pre-service English teachers based on their performance in the teaching and learning process. The feedback, guidance, and exemplary lessons shared were parts of intervention in the microteaching class.

\section{Data Analysis}

Data were quantitatively analyzed using SPSS version 21 . It included the descriptive statistics, involving minimum and maximum scores, mean, standard deviation, and the inferential statistics comprising paired samples t-test and the N-gain. According to Pallant (2014), the paired-samples t-test is used to compare a number of measurements of the same variable within a single group. Therefore, this research determined the statistical significance of pre-service English teachers' PCK using the generalized linear model (GLM) repeated measures test.

\section{Trustworthiness}

The triangulation and inter-rater methods were employed to determine the trustworthiness of this study. The triangulation employed in this study involves multiple theories, observers, data sources, and methods (Cohen, Manion \& Morrison, 2007; Heale \& Forbes, 2013). On the other hand, the inter-raters involved in this study were three observers comprising an expert secondary English teacher that taught the microteaching class and the two lecturers as observers.

The Intraclass Correlation Coefficients (ICC) were used to examine inter-rater reliability because three raters were involved in the study. Furthermore, the raters used 
repeated measures and two-way mixed-effects to assign multiple scores (Shrout \& Fleiss, 1979). The first PCK of pre-service English teachers' inter-rater reliability shows that the ICC is 0.86 at a $95 \%$ confidence interval of $0.75-0.90$, categorized at good reliability. The different results occurred in the second PCK, which shows that the ICC is 0.97 with a $95 \%$ confidence interval above 0.90 , therefore, the reliability is excellent. A similar result is also found in the third and fourth PCK with the ICC of the third PCK at 0.97, with a $95 \%$ confidence interval above 0.90 . This means that the value is categorized at excellent reliability. The last is the fourth PCK with an ICC value of 0.94 , at a 95\% confidence interval above 0.90 , therefore, the reliability is also excellent.

\section{Findings}

\section{The Changes in Pre-service English Teachers' Pedagogical Content Know-} ledge (PCK) before and after Participating in Expert-Guided Microteaching

\section{The Descriptive Statistics Analysis}

Table 1 shows the descriptive statistics of the minimum, maximum, mean, and standard deviation of the first pedagogical content knowledge (PCK) of pre-service English teachers before participating in expert-guided microteaching.

Table 1

The Descriptive Statistics of the First PCK of Pre-Service English Teachers before Participating in Expert-Guided Microteaching

\begin{tabular}{lccccc}
\hline & N & Minimum & Maximum & Mean & Std. Deviation \\
\hline PCK 1 & 11 & 1.675 & 2.3 & 1.979 & .210 \\
\hline Valid N (listwise) & 11 & & & & \\
\hline
\end{tabular}

Table 1 shows that the minimum, maximum, mean, and standard deviation of the first PCK of pre-service English teachers before participating in expert-guided microteaching are $1.675,2.3,1.979$, and 0.210 .

The descriptive statistics of the second PCK of pre-service English teachers participating in expert-guided microteaching also present the minimum, maximum, mean, and standard deviation, as shown in Table 2. 
Table 2

The Descriptive Statistics of the Second PCK of Pre-Service English Teachers

Participating in Expert-Guided Microteaching

\begin{tabular}{lccccc}
\hline & N & Minimum & Maximum & Mean & Std. Deviation \\
\hline PCK 2 & 11 & 2.075 & 3.2 & 2.627 & .460 \\
\hline Valid N (listwise) & 11 & & & & \\
\hline
\end{tabular}

Furthermore, the descriptive statistics of the second PCK of pre-service English teachers in expert-guided microteaching, compared with the previous result, show an increase in minimum, maximum, mean, and standard deviation in values of 2.075, 3.2. 2.627 and 0.460 , respectively.

The next data shows the descriptive statistics of the third PCK of pre-service English teachers participating in expert-guided microteaching.

Table 3

The Descriptive Statistics of the Third PCK of Pre-Service English Teachers Participating in Expert-Guided Microteaching

\begin{tabular}{lccccc}
\hline & N & Minimum & Maximum & Mean & Std. Deviation \\
\hline PCK 3 & 11 & 2.6 & 3.725 & 3.247 & .409 \\
\hline Valid N (listwise) & 11 & & & & \\
\hline
\end{tabular}

The descriptive statistics show that in the third PCK, the minimum, maximum, mean, and standard deviation obtained were higher than the second PCK with values of 2.6, $3.725,3.247$, and 0.409 .

The last data were descriptively obtained from the fourth PCK of pre-service English teachers after participating in expert-guided microteaching, as shown in Table 4.

Table 4

The Descriptive Statistics of the Fourth PCK of Pre-Service English Teachers after Participating in Expert-Guided Microteaching

\begin{tabular}{lccccc}
\hline & N & Minimum & Maximum & Mean & Std. Deviation \\
\hline PCK 3 & 11 & 2.9 & 3.875 & 3.454 & .314 \\
\hline Valid N (listwise) & 11 & & & & \\
\hline
\end{tabular}

The descriptive statistics data show an increase in the minimum, maximum, mean, and standard deviation scores obtained in the fourth PCK of pre-service English teachers after participating in expert-guided microteaching by $2.9,3.875,3.454$, and 0.314 , respectively. These scores were higher than the third PCK. 
The inferential statistics is needed to calculate the pre-service English teachers' efficiency to determine their changes. Furthermore, the paired-sample t-test was examined using the generalized linear model (GLM) repeated measures to test, and the normalized (N)-gain.

\section{The Generalized Linear Model (GLM) Repeated Measures Test}

The generalized linear model (GLM) repeated measures test is used to compare the mean value of pedagogical content knowledge (PCK) of pre-service English teachers participating in expert-guided microteaching.

Mauchly's test of sphericity is first examined in the GLM repeated measures to test to analyze the hypothesis whether the relationship between pairs of variables is equal (Field, 2013). The null hypothesis is rejected, assuming the Mauchly's sphericity test is statistically significant $(p<0.05)$. This means that there are significant differences between pairs of variables, and therefore, the assumption of sphericity is violated. Meanwhile, the null hypothesis is accepted, assuming the Mauchly's test is not significant $(p<0.05)$. Hence, there are no significant differences between pairs of variables, and the assumption of sphericity is not violated.

The following table presents the result of Mauchly's test of sphericity of pre-service English teachers' PCK participating in expert-guided microteaching.

Table 5

The Result of Mauchly's Test of Sphericity

\begin{tabular}{|c|c|c|c|c|c|c|c|}
\hline \multirow[b]{2}{*}{$\begin{array}{c}\text { Within } \\
\text { Subjects Effect }\end{array}$} & \multirow[b]{2}{*}{$\begin{array}{c}\text { Mauchly's } \\
\text { W }\end{array}$} & \multirow[b]{2}{*}{$\begin{array}{c}\text { Approx. } \\
\text { Chi-Square }\end{array}$} & \multirow[b]{2}{*}{ df } & \multirow[b]{2}{*}{ Sig. } & \multicolumn{3}{|c|}{ Epsilon $^{\mathrm{a}}$} \\
\hline & & & & & $\begin{array}{c}\text { Greenhouse- } \\
\text { Geisser }\end{array}$ & $\begin{array}{l}\text { Huynh- } \\
\text { Feldt }\end{array}$ & $\begin{array}{l}\text { Lower- } \\
\text { bound }\end{array}$ \\
\hline & & & 5 & & .782 & 1.000 & .333 \\
\hline
\end{tabular}

The result showed that the sphericity of the $p$-value is 0.430 and greater than 0.05 $(0.430>0.05)$. Therefore, the null hypothesis is rejected, which means that the assumption of sphericity is not violated. This also indicates no significant differences among PCK of pre-service English teachers participating in expert-guided microteaching. Subsequently, the row of sphericity assumed in the test within-subjects effects are insignificant.

The assumed sphericity result indicates that the significant value is 0.000 and lower than the alpha value of $0.05(0.000<0.05)$, therefore, the null hypothesis is rejected. It means that there is a significant difference among PCK of pre-service English teachers participating in expert-guided microteaching. Furthermore, it can also be stated that the expert-guided microteaching significantly affect the pre-service English teachers' PCK. 
Table 6

The Result of the Test Within-Subjects Effects

\begin{tabular}{llccccc}
\hline \multicolumn{1}{c}{ Source } & $\begin{array}{c}\text { Type III Sum } \\
\text { of Squares }\end{array}$ & df & $\begin{array}{c}\text { Mean } \\
\text { Square }\end{array}$ & F & Sig. \\
\hline Expert-Guided & Sphericity Assumed & 14.618 & 3 & 4.873 & 165.179 & .000 \\
Microteaching & Greenhouse-Geisser & 14.618 & 2.346 & 6.230 & 165.179 & .000 \\
& Huynh-Feldt & 14.618 & 3.000 & 4.873 & 165.179 & .000 \\
& Lower-bound & 14.618 & 1.000 & 14.618 & 165.179 & .000 \\
\hline Error & Sphericity Assumed & .885 & 30 & .029 & & \\
(Expert-Guided & Greenhouse-Geisser & .885 & 23.462 & .038 & & \\
Microteaching) & Huynh-Feldt & .885 & 30.000 & .029 & & \\
& Lower-bound & .885 & 10.000 & .088 & & \\
\hline
\end{tabular}

The significant differences among the four data of PCK of pre-service English teachers participating in expert-guided microteaching are determined using the pairwise comparison.

Table 7

The Pairwise Comparison

\begin{tabular}{|c|c|c|c|c|c|c|}
\hline \multirow{2}{*}{$\begin{array}{c}\text { (I) } \\
\text { Expert-Guided } \\
\text { Microteaching }\end{array}$} & \multirow{2}{*}{$\begin{array}{l}\text { (J) } \\
\text { Expert-Guided } \\
\text { Microteaching }\end{array}$} & \multirow{2}{*}{$\begin{array}{c}\text { Mean } \\
\text { Difference } \\
(\mathrm{I}-\mathrm{J}) \\
\end{array}$} & \multirow{2}{*}{$\begin{array}{l}\text { Std. } \\
\text { Error }\end{array}$} & \multirow[t]{2}{*}{ Sig. ${ }^{a}$} & \multicolumn{2}{|c|}{$\begin{array}{l}\text { 95\% Confidence Interval for } \\
\text { Difference }^{s}\end{array}$} \\
\hline & & & & & Lower Bound & Upper Bound \\
\hline \multirow[t]{3}{*}{1} & 2 & $-.648^{*}$ & .088 & .000 & -.937 & -.358 \\
\hline & 3 & $-1.268^{*}$ & .079 & .000 & -1.529 & -1.008 \\
\hline & 4 & $-1.475^{*}$ & .067 & .000 & -1.693 & -1.257 \\
\hline \multirow[t]{3}{*}{2} & 1 & $.648^{*}$ & .088 & .000 & .358 & .937 \\
\hline & 3 & $-.620^{*}$ & .063 & .000 & -.828 & -.413 \\
\hline & 4 & $-.827^{*}$ & .083 & .000 & -1.098 & -.556 \\
\hline \multirow[t]{3}{*}{3} & 1 & $1.268^{*}$ & .079 & .000 & 1.008 & 1.529 \\
\hline & 2 & $.620^{*}$ & .063 & .000 & .413 & .828 \\
\hline & 4 & $-.207^{*}$ & .053 & .017 & -.379 & -.034 \\
\hline \multirow[t]{3}{*}{4} & 1 & $1.475^{*}$ & .067 & .000 & 1.257 & 1.693 \\
\hline & 2 & $.827^{*}$ & .083 & .000 & .556 & 1.098 \\
\hline & 3 & $.207^{*}$ & .053 & .017 & .034 & .379 \\
\hline
\end{tabular}

The pairwise comparison result shows an increase between the first and second PCK, by 0.648 , with a significant value of 0.000 . Meanwhile, an alpha value lower than 0.05 $(0.000<0.05)$ shows a statistically significant difference between the first and second PCK of pre-service English teachers before participating in expert-guided microteaching. Therefore, it can be stated that the expert-guided microteaching affects the first and second PCK of pre-service English teachers. 
The increase in mean difference by 1.268 also occurs between the first and third PCK. The significance is 0.000 , which is less than the alpha value of $0.05(0.000<0.05)$. Therefore, there is a significant difference between the first and third PCK of pre-service English teachers before participating in expert-guided microteaching. In other words, the first and third PCK of pre-service English teachers is significantly influenced by expert-guided microteaching.

The next comparison is between the first and fourth PCK, with a mean difference of 1.475 and a significant value of 0.000 . This value is lower than the alpha value of 0.05 $(0.000<0.05)$, therefore, there is a significant difference between the first and fourth PCK of pre-service English teachers before participating in expert-guided microteaching. It can also be inferred that expert-guided microteaching affects the first and fourth PCK of pre-service English teachers.

Between the second and third PCK, there is also an increase in the mean difference by 0.620 , with a significance of 0.000 , which is less than the alpha value of $0.05(0.000<$ $0.05)$. In other words, there is a statistically significant difference between the second and third PCK of pre-service English teachers participating in expert-guided microteaching. Therefore, the second and third PCK of pre-service English teachers is affected by expert-guided microteaching.

Meanwhile, the significant value of the second and fourth PCK is 0.000 , with a mean difference of 0.827 . The significant value is lower than the alpha of $0.05(0.000<0.05)$, which means a significant difference exists between the second and fourth PCK of pre-service English teachers participating in expert-guided microteaching. Therefore, it can be concluded that expert-guided microteaching significantly influences the second and fourth PCK of pre-service English teachers.

The last comparison happens in the third and fourth PCK in which the significant at 0.017 and less than the alpha value of $0.05(0.017<0.05)$. It means that there is a significant difference between the third and fourth PCK of pre-service English teachers participating in expert-guided microteaching. Therefore, the third and fourth PCK of pre-service English teachers are significantly affected by expert-guided microteaching.

Table 8 determines the significant difference for each aspect of the multivariate tests.

Table 8

The Multivariate Tests

\begin{tabular}{llccccc}
\hline \multicolumn{2}{c}{ Effect } & Value & F & Hypothesis df & Error df & Sig. \\
\hline Expert-Guided & Pillai's Trace & .980 & $134.053^{\mathrm{a}}$ & 3.000 & 8.000 & .000 \\
Microteaching & Wilks' Lambda & .020 & $134.053^{\mathrm{a}}$ & 3.000 & 8.000 & .000 \\
& Hotelling's Trace & 50.270 & $134.053^{\mathrm{a}}$ & 3.000 & 8.000 & .000 \\
& Roy's Largest Root & 50.270 & $134.053^{\mathrm{a}}$ & 3.000 & 8.000 & .000 \\
\hline
\end{tabular}


The multivariate test result indicates that the $p$-value for each aspect is 0.000 and lower than the alpha value of $0.05(0.000<0.05)$. Therefore, there is a statistically significant difference among PCK of pre-service English teachers participating in expert-guided microteaching.

\section{The Normalized Gain (N-gain)}

The Normalized Gain is used to determine the extent to which expert-guided microteaching significantly changes in pre-service English teachers' PCK. Furthermore, the calculation result shows that the normalized gain (N-gain) for the data of pre-service English teachers' PCK is 0.777 and above $0.7(0.777<0.7)$, which means that it is the high category (Hake (1998). Therefore, the pre-service English teachers' PCK improves adequately after participating in expert-guided microteaching.

\section{Discussion}

This study confirms that expert-guided microteaching affects the pre-service English teachers' PCK and is affected by expert-guided microteaching. Further, the pre-service English teachers are mandated to design a lesson plan, implement the instructional process based on the designed lesson plan, easily explain the subject matter, provide the contextual examples to support the explanation, and evaluate students' understanding improves significantly.

The condition is apparently different from when they joined the pedagogical courses, which enabled them to learn only as prerequisites before taking the practical courses such as teaching internship. Initially, some pre-service English teachers did not realize the need to comprehend those courses properly before implementing it in their teaching practices. Therefore, when they have to practice their teaching in front of peers, they unconsciously make some efforts to develop their PCK by joining some expert-guided microteaching in order to implement effective teaching. It proves that expert-guided microteaching triggered pre-service English teachers to increase their awareness in developing their PCK base of implementing effective teaching. These results are in accordance with the studies carried out by Chan \& Yuang (2018), Day (n.d), Fernandez (2014), König, Lammerding, Nold, Rohde, Strauß, \& Tachtsoglou (2016), and Fandiño (2013). They argued that effective teaching was determined by the teacher's PCK, i.e., the ability to design lesson plans, simplify and explain the subject matter, choose the appropriate teaching strategies, counter students' learning problems, and reflect the teaching and learning process.

Therefore, this study focuses on the four components of PCK, namely subject matter knowledge (SMK), instructional representation and strategies (IRS), instructional objective and context (IOC), and knowledge of students' understanding (KSU). According to Uygun \& Akyüz (2019) SMK, help pre-service English teachers carry out 
the instructional processes, they deepened their knowledge on the subject matter. This also enables pre-service English teachers to learn the strategies associated with involving students in solving their learning problems, ways to answer their questions, and check their work (Ball et al., 2008). Furthermore, without adequate knowledge of the teaching process, they realized that they can help their students solve problems. Therefore, the teacher education program, which aides them to become professional English teachers, needs to prepare and equip them with the right teaching knowledge.

Expert-guided microteaching enabled pre-service English teachers to learn more through some exemplary lessons (Cheng, 2017). The expert teacher did not only guide them to improve their teaching performance where microteaching was commonly focused, rather they emphasized the weaknesses of PCK. SMK is crucial to develop since pre-service English teachers need to know their students' right things. This is in line with Nixon, Hill, \& Luft's (2017) study, which stated that pre-service English teachers' SMK are developed through classroom experiences, which enabled them to practice their teaching. This condition encouraged them to be more focus on their SMK, which is very crucial to teach. They were demanded to understand the content taught to students (Ball et al., 2008) besides having knowledge of pedagogy. Therefore, by having good teaching chances, they learned to evaluate the success achieved from their previous teaching. They also learned from constructive feedback delivered by the expert teacher and peers from either the weaknesses or the strengths of the teaching performance. The detailed information delivered by the expert teacher and peers through feedback, regarding the achievement in the teaching and learning process, made pre-service English teachers more aware of the attributes to be refined and improved. This is in line with the feedback provided by Hattie \& Timperley (2007) to determine the right processes. Feedback, encourages pre-service English teachers to make reflections and improves their teaching performance (Baseer, Mahboob, \& Degnan, 2017; Poulos \& Mahony, 2008). This finding is contrary to the initial condition whereby the lecturer commonly focused only on pre-service English teachers' weaknesses during teaching, which discouraging their teaching process. AlBashir, Kabir, \& Rahman (2016) stated that feedback does not need to be discouraging, rather it encourages refinement. Also, in the former microteaching class, it was also found that peers' feedback did not give much input to the others' teaching performance. Peers that felt inconvenient to convey the weaknesses of the performance only focused on the strengths. The unavailability of the assessment sheet as a reference to assess the performance and provide feedback became one reason for peers to focus on the strengths of the performance. Consequently, pre-service English teachers failed to realize when their teaching performance needs to be refined and improved.

Regarding IRS's category, to optimize student-centered learning, the majority of the pre-service English teachers focused more on students and the teaching and learning process. The emphasis in this approach lies in the interaction between teachers and students, as well as students and students. It aims to facilitate students' learning adjusted with 
their needs of learning (Beausaert, Segers, \& Witlink, 2013). Therefore, at this point, preservice English teachers explored the use of teaching approaches, such as games combined with multimedia to attract students' interest (Krieger, 2005). In this aspect, pre-service English teachers used various teaching approaches to make the subject matter comprehensive. Besides attracting students' interests, the use of multimedia aimed to optimize their learning (Manikowati \& Bharati, 2017), offer comfortable learning environments, enhance their interests and enthusiasm (Barzegar, Farjad, \& Hosseini, 2012; Skinner, Furrer, Marchand, \& Kindermann, 2008), and increase the interaction between students and teachers (Rajendra \& Sudana, 2018). Furthermore, through the use of various teaching approaches, which focus on student-centered learning, the students were opportune to perform and express their ideas during class. This is in line with the research carried out by Intarapanich (2013), which stated that the use of teaching approaches and activities enable students to develop their communication skills and use the classroom language optimally. This finding confirms the theory of constructivism in which teachers need to facilitate the teaching process by encouraging students to discuss and share information with others (Beausaert et al., 2013).

The IOC component deals with understanding the course's objective and encouraging pre-service English teachers to teach their students based on the learning objectives formulated on Bloom's Taxonomy (Mitchell \& Manzo, 2018). By clearly formulating the learning objective, they are able to understand the paths of learning to be followed, encourage students to be aware of the factors they need to achieve at the end of the learning process (Mahajan \& Singh, 2017; Mitchell \& Manzo, 2018), and focus on the results (Erikson \& Erikson, 2018). Moreover, the learning objective also encouraged pre-service English teachers to critically determine the level of subject matter mastery expected from their students (Faulconer, 2017) and enables them to check the effectiveness of their teaching strategies (Mitchell \& Manzo, 2018). Therefore, formulating the learning objective triggers them to prepare and provide authentic materials (Pinter, 2006; Rahimi, 2008; Seven \& Engin, 2007), which saves students from their deficiencies (Allwright, 1981) and exposes their ability to use language as a means of communication (Al Azri \& Al-Rashdi, 2014).

Yuksel (2012) stated that prior knowledge is part of the KSU, essential in the teaching and learning process. Pre-service English teachers helped improve students' knowledge to quickly understand the topic discussed (Tawalbeh \& Al-Zuoud, 2013; Yuksel, 2012). Evaluating students' understanding also became crucial in the teaching and learning process because it allowed them to provide some questions and assignments. By posing some questions, pre-service English teachers can ascertain their level of understanding (Aimah \& Purwanto, 2019; Jabbarifar, 2009). Furthermore, assignments also played important roles in determining students' participation in the classroom (Buijs \& Admiraal, 2013). At this point, pre-service English teachers plan the activities mandated for students to stimulate their participation in the classroom, which aids in improving their knowledge (Latif \& Miles, 2011). 
From those explanations, microteaching guided by an expert secondary English teacher significantly gives an effect on the changes in pre-service English teachers' PCK. Under expert-guided microteaching, they demonstrated their understanding of the subject and explained it clearly and concisely. This is in line with the previous studies that stated that strong PCK enables teachers to clearly and easily explain the subject matter (Even, 1990; Shulman, 1987; Suhirman, 2018). At this point, pre-service English teachers realized the importance of understanding the theories and principles of the subject. Those needs triggered them to construct their knowledge based on their teaching experiences to teach English effectively to students (Uygun \& Akyüz, 2019). When they were able to ascertain their understanding of the content, they predicted students' achievement levels (Ball et al., 2008). Students' achievement of the learning process was determined by pre-service English teachers' ability to understand students' needs, including their learning activities, giving clear explanations, asking further questions, and evaluating their understanding (Ball \& McDiarmid, n.d).

Although pre-service English teachers' PCK improved after expert-guided microteaching, some lacked understanding of the learning objectives. The common mistakes influenced the failure of achieving the intended learning objective. However, this finding contradicts the studies carried out by Mahajan \& Singh (2017) and Mitchell \& Manzo (2018), which stated that learning objectives helped teachers keep the focus of their achievement.

The research also confirms that not all pre-service English teachers are able to evaluate students' understanding at the beginning, middle, or end of the learning process. This is because they only provided students with assignments and grouped them during learning activities. The discussion was commonly chosen because it enabled students to express their opinion and convey their arguments. Furthermore, students actively increase their interaction in groups (Uygun \& Akyüz, 2019). Therefore, their understanding of the subject matter became better. However, at the end of the learning process, pre-service English teachers did not evaluate students' understanding of the subject due to poor time management.

\section{Conclusion}

In conclusion, this study proved that the ability and appropriateness of pre-service English teachers in designing a lesson plan, choosing the appropriate teaching strategies, simplifying and explaining the subject matter, designing the learning activities, and evaluating students' understanding aids to determine the extent to which the success of the implementation of effective teaching.

As a teacher education program that prepares pre-service English teachers to be professional, the expert teacher's involvement in the microteaching class played an important role in assisting pre-service English teachers in developing their PCK and improving their 
teaching performance. Furthermore, those that previously lacked PCK made considerable progress in refining and improving their performance based on the expert teacher's constructive feedback, guidance, and exemplary lessons shared with them.

The implication of this study shows that PCK is crucial in preparing teaching practices for pre-service English teachers. Ball \& MacDiarmid (n.d) and Uygun \& Akyüz (2019) stated that PCK can be developed from the way pre-service English teachers construct their knowledge based on their teaching experiences. Therefore, they need more teaching practices of different content to build and strengthen their knowledge to teach.

\section{References}

Adi, I. P. P. (2015). Evaluation system and readiness for teaching practice experience in partner schools. Jurnal Pendidikan Indonesia, 4(2), 657-665.

Afrilianti, R. D., Ulfah, M., \& Achmadi, A. (1996). School teachers' perceptions of pre-service economic students' teaching skills at SMK Pontianak. Jurnal Pendidikan dan Pembelajaran Untan, 1-13.

Aimah, S, Ifadah, M, \& Bharati, D. A. L. (2017). Building Teacher's Pedagogical Competence and Teaching Improvement through Lesson Study. Arab World English Journal (AWEJ), 8(1), 66-78. doi: 10.24093/awej/vol8nol.6

Aimah, S., \& Purwanto, B. (2019). The use of teachers' questioning strategies to stimulate students' critical literacy: A case of two English lecturers in Indonesia. Indonesian EFL Journal, 5(1), 27-36. doi: 10.25134/ieflj.v5i1.1608

Aksu, Z., Metin, M., \& Konyalioğlu, A. C. (2014). Development of the pedagogical content knowledge scale for pre-service teachers: The validity and realibility study. Meditteranian Journal of Social Sciences, 5(20), 1365-1377. doi: 10.5901/mjss.2014.v5n20p1365

Allen, D. W. (1967). Micro-teaching. A description. California: Stanford University.

Allwright, R. L. (1981). What do we want teaching materials for? ELT Journal, 36(1), 5-18.

Al Azri, R. H., \& Al-Rashdi, M. H. (2014). The effect of using authentic materials in teaching. International Journal of Scientific \& Technology Research, 3(10), 249-254.

Al-Bashir, M., Kabir, R., \& Rahman, I. (2016). The value and effectiveness of feedback in improving students' learning and professionalizing teaching in higher education. Journal of Education and Practice, 7(16), 38-41.

Bahjat, A. (2016). Effectiveness of using microteaching and thinking style to develop teaching skills in Arab Open University - Jordan Branch. International Journal of Learning, Teaching and Educational Research, 15(3), 118-133.

Baker, M., \& Chick, H. (2006). Pedagogical content knowledge for teaching primary Mathematics: A case study of two teachers. MERGA 29: Proceedings of the 29th Conference of the Mathematics Education Research Group of Australasia, 1(60-67). http://citeseerx.ist.psu.edu/viewdoc/dow nload?doi=10.1.1.496.7385\&rep=rep1\&type=pdf 
Bakir, S. (2014). The Effect of microteaching on the teaching skills of preservice science teachers. Journal of Baltic Science Education, 13(6), 789-801.

Ball, D. L., \& McDiarmid, G. W. (n.d). The subject matter preparation of teachers. In W. R. Houston (Ed.), Handbook for research on teacher education. New York: Macmillan.

Ball, D. L., Thames, M. H., \& Phelps, G. (2008). Content knowledge for teaching. Journal of Teacher Education, 59(5), 389-407. doi: 10.1177/0022487108324554

Ballmart, J., \& Kunter, M. (2006). The COACTIV model of teachers' professional competence. In M. Kunter et.al. (Eds.), Cognitive activation in the mathematics classroom and professional competence of teachers, Mathematics Teacher Education 8, Springer Science + Business Media New York. doi: 10.1007/978-1-4614-5149-5_2

Banga, C. L. (2014). Microteaching, an efficient technique for learning effective teaching. Scholarly Research Journal for Interdisciplinary Studies, II(XV), 2206-2211.

Barzegar, N., Farjad, S., \& Hosseini, N. (2012). The effect of teaching model based on multimedia and network on the student learning (Case study: Guidance schools in Iran). Procedia-Social and Behavioral Sciences, 47, 1263-1267. doi:10.1016/j.sbspro.2012.06.809

Baseer, N., Mahboob, U., \& Degnan, J. (2017). Micro-feedback training: Learning the art of effective feedback. Pakistan Journal of Medical Sciences, 33(6), 1525-1527. doi:10.12669\%2fpjms.336.13721

Baştürk, S. (2016). Investigating the effectiveness of microteaching in mathematics of primary pre-service teachers. Journal of Education and Training Studies, 4(5), 239-249.

Beausaert, S. A. J., Segers, M. S. R., \& Witlink, D. P. A. (2013). The influence of teachers' teaching approaches on students' learning approaches: The student perspective. Educational Research, 55(1), 1-15. doi: 10.1080/00131881.2013.767022

Berger, J. L., Girardet, C., Vaudroz, C., \& Crahay, M. (2018). Teaching experience, teachers' beliefs, and self-reported classroom management practices: A coherent network. Sage Open, 1-12. doi: $10.1177 / 2158244017754119$

Berliner, D. C. (2001). Learning about and learning from expert teachers. International Journal of Educational Research, 35, 463-482. doi: 10.1016/S0883-0355(02)00004-6

Bertus, Matsum, J., \& Syahrudin, H. (2018). School Teachers' Perceptions of pre-service economics teachers' Professional Competencies of PPL 2 at SMK 1 Pontianak. Jurnal Pendidikan dan Pembelajaran Khatulistiwa, 7(4), 1-12.

Bertram, C., \& Christiansen, I. M. (2012). Teacher knowledge \& learning perspectives \& reflections. Journal of Education, 56, 1-16.

Bidabadi, N. S., Isfahani, A. N., Rouhollahi, A., \& Khalili, R. (2016). Effective teaching methods in higher education: requirements and barriers. Journal of Advances of Medical Education and Professionalism, 4(4), 170-178.

Birel, G. K., \& Çakiroğlu, E. (2018). Preservice mathematics teachers' TPACK development in statistics teaching: A microteaching lesson study. Proceeding of the Tenth International conference on Teaching Science (ICOTS10). 
Buijs, M., \& Admiraal, W. (2013). Homework assignments to enhance student engagement in secondary education. European Journal Psychological Education, 28, 767-779. doi: 10.1007/ s10212-012-0139-0

Carter, K., Cushing, K., Sabers, D., Stein, P., \& Berliner, D. (1988). Expert-novice differences in perceiving and processing visual classroom information. Journal of Teacher Education, 25-31. doi: $10.1177 / 002248718803900306$

Cavin, R. M. (2007). Developing technological pedagogical content knowledge in preservice teachers through microteaching lesson study. Doctoral dissertation. Florida: The Florida State University.

Carlsen, W. (1999). Domains of teacher knowledge. In J. Gess-Newsome \& G. Lederman, Norman (Eds.), Examining Pedagogical Content Knowledge (pp. 133-137). Dordrecht: Kluwer Academic Publishers.

Chan, K. K. H., \& Yung, B. H. W. (2018). Developing pedagogical content knowledge for teaching a new topic: more than teaching experience and subject matter knowledge. Res Sci Educ, 48, 233-265. doi: 10.1007/s11165-016-9567-1

Cheng, J. (2017). Learning to attend to precision: The impact of micro-teaching guided by expert secondary mathematics teachers on pre-service teachers' training practice, ZMD Mathematics Ecucation, 49, 279-289.

Chi, M. T. H. (2006). Two approaches to the study of experts' characteristics. The Cambridge Handbook of Expertise and Expert Performance, 6(36), 21-30.

Cobilla, C. H. (2014). Exposure of pre-service teachers to microteaching. Journal of Educational and Human Resource Development, 2, 207-215.

Cohen, L., Manion, L., \& Morrison, K. (2007). Research methods in education. London: Routledge. Copeland, W. D. (1975). The relationship between microteaching and student teacher classroom performance. The Journal of Educational Research, 68(8), 289-293. doi: 10.1080/00220671.1975.10884776

Copeland, W. D., Birmingham, C., DeMeulle, L., D’Emidio-Caston, M., \& Natal, D. (1994). Making meaning in classrooms: An investigation of cognitive processes in aspiring teachers, experienced teachers, and their peers. American Educational Research Journal, 31(1), 166-196. doi: 10.3102/00028312031001166

Day, R. (n.d). Models and the knowledge base of second language teacher education. University of Hawai'i Working Papers in ESL, 11(2), 1-13. https://core.ac.uk/download/pdf/77238786.pdf

Diamond, B. S., Maerten-Rivera, J., Rohrer, R. E., \& Lee, O. (2014). Effectiveness of a curricular and professional development intervention at improving elementary teachers' science content knowledge and student achievement outcomes: Year 1 results. Journal of Research in Science Teaching, 51(5), 635-658. doi: 10.1002/tea.21148

Donnelly, R., \& Fitzmaurice, M. (2011). Towards productive reflective practice in microteaching. Innovations in Education and Teaching International, 48(3), 335-346. doi: 10.1080/14703297.2011.593709 
Driel, J. H., Verloop, N., \& Vos, W. (1998). Developing science teachers' PCK. Journal of Research in Science Teaching, 35(6), 673-695. doi: 10.1002/(sici)1098-2736(199808)35:6<673::aidtea5 $>3.0 . c 0 ; 2-\mathrm{j}$

Elias, S. K. (2018). Pre-service teachers' approaches to the effectiveness of micro-teaching in teaching practice program. Open Journal of Social Sciences, 6, 205-224. doi: 10.4236/ JSS.2018.65016

Erikson, M. G., \& Erikson, M. (2018). Learning outcomes and critical thinking-good intensions in conflict. Studies in Higher Education, 1-11. doi: 10.1080/03075079.2018.1486813

Even, R. (1993). Subject matter knowledge for teaching and the case of functions. Educational Studies in Mathematics, 21, 521-544.

Faisal (2015). Pedagogical content knowledge in Indonesian English language teaching. Asia Pacific Journal of Multidisciplinary Research, 3(5), 103-110.

Fandiño, Y. (2013). Knowledge base and EFL teacher education programs: A Colombian perspective. Íkala, revista de lenguaje y cultura, 18(1), 83-95.

Faulconer, E. K. (2017). Increasing student interactions with learning objectives. Journal of College Science Teaching, 46(5), 32-38.

Fernandez, M. L. (2010). Investigating how and what prospective teachers learn through microteaching lesson study. Teaching and Teacher Education, 26, 351-362. doi: 10.1016/j. tate.2009.09.012

Fernandez, C. (2014). Knowledge base for teaching and pedagogical content knowledge (PCK): Some useful models and implications for teachers' training. Problems of Education in the $21^{\text {st }}$ Century, 60, 79-100.

Field, A. (2013). Discovering statistics using IBM SPSS statistics (4th ed.). Los Angeles: SAGE Publication Ltd.

Geddis, A. N. (1993). Transforming subject-matter knowledge: The role of pedagogical content knowledge in learning to reflect on teaching. International Journal of Science Education, 15(6), 673-683. doi:10.1080/0950069930150605

Gess-Newsome, J. (1999). The complex nature and sources of teachers' pedagogical knowledge. In J. Gess-Newsome \& N. G. Lederman (Eds.), PCK and Science Education (pp. 3-17). Netherlands: Kluwer Academic Publishers.

Gess-Newsome, J. (1999). Pedagogical content knowledge: An introduction and orientation. In J. Gess-Newsome \& N. G. Lederman (Eds.), PCK and Science Education (pp. 3-17). Netherlands: Kluwer Academic Publishers.

Ghazi, S. R., Shahzada, G., Shah, M. T., \& Shauib, M. (2013). Teacher's professional competencies in knowledge of subject matter at secondary level in Southern Districts of Khyber Pakhtunhwa, Pakistan. Journal of Educational and Social Research, 3(2), 453-460.

Ghanaguru, S., Nair, P., \& Yong, C. (2013). Teacher trainers' beliefs in microteaching and lesson planning in a teacher training institution. The English Teacher, XLII(2), 104-116.

Gödek, Y. (2016). Science teacher trainees' microteaching experiences: A focus group study. Educational Research and Reviews, 11(16), 1473-1493. doi: 10.5897/err2016.2892 
Gorgoretti, B. \& Pilli, O. (2012). Pre-service teachers' view on the effectiveness of teaching practice course. Procedia - Social and Behavioral Sciences, 47, 812-817. doi: 10.1016/j.sbspro.2012.06.740

Großschedl, J., Welter, V., \& Harms, U. (2018). A new instrument for measuring pre-service biology teachers' pedagogical content knowledge: The PCK-IBI. J Res Sci Teach, 1-38. doi: 10.1002/tea.21482

Gurney, P. (2007). Five factors for effective teaching. New Zealand Journal of Teachers' Work, 4(2), 89-98.

Gün, B. (2014). Making sense of experienced teachers' interactive decisions: Implications for expertise in teaching. International Journal of Instruction, 7(1), 75-90.

Hammond, J., Burns, A., Joyce, H., Brosnan, D., \& Gerot, L. (1992). English for social purposes. A handbook for teachers of adult literacy. Sydney: Macquarie University.

Harris, J., Mishra, P., \& Koehler, M. (2009). Teachers' technological pedagogical content knowledge \& learning activity types: Curriculum-based technology integration reframed. Journal of Research on Technology in Education, 41(4), 393-416.

Hattie, J. \& Timperley, H. (2007). The power of feedback. Review of Educational Research, 77(1), 81-112. doi: 10.3102/003465430298487

Hudson, P., English, L., Dawes, L., King, D., \& Baker, S. (2015). Exploring links between pedagogical content knowledge practices and student outcomes in STEM education for primary schools. Australian Journal of Teacher Education, 40(6), 134-151. doi: 10.14221/ajte.2015v40n6.8

Heale, R., \& Forbes, D. (2013). Understanding triangulation in research. Evid Based Nurs, 16(4), 98-98. doi: 10.1136/eb-2013-101494

Intarapanich, C. (2013). Teaching methods, approaches and strategies found in EFL classrooms: A case study in Lao PDR. Procedia-Social and Behavioral Sciences, 88, 306-311. doi: 10.1016/j. sbspro.2013.08.510

Ismail, S. A. A. (2011). Student teachers' microteaching experiences in a preservice English teacher education program. Journal of Language Teaching and Research, 2(5), 1043-1051. doi:10.4304/ jltr.2.5.1043-1051

Jabbarifar, T. (2009). The importance of classroom assessment and evaluation in educational system. Proceedings of the 2nd International Conference of Teaching and Learning (ICTL 2009). INTI University College, Malaysia.

Jang, S. J, Guan, S. Y, \& Hseieh, H. F. (2009). Developing an instrument for assessing college students' perceptions of teachers' pedagogical content knowledge. Procedia Social and Behavioral Sciences, 1, 596-606. doi:10.1016/j.sbspro.2009.01.107

Kamimura, T., \& Takizawa, T. (n.d). The effects of peer feedback on student teacher's teaching demonstrations in an EFL teacher training course in Japan. https://core.ac.uk/download/ pdf/71787981.pdf

Kiliç, A. (2010). Learner-centered micro teaching in teacher education. International Journal of Instruction, 3(1), 77-100.

Kourieos, S. (2014). The knowledge base of primary EFL teachers-pre-service and in-service teachers' perception. Journal of Language Teaching and Research, 5(2), 291-300. doi: 10.4304/jltr.5.2.291-300 
Krieger, D. (2005). Teaching ESL versus EFL: Principles and practices. English Teaching Forum, 43(2), 8-16.

Kleickmann, T., Richter, D., Kunter, M., Elsner, J., Besser, M., Krauss, S., \& Baumert, J. (2013). Teachers' content knowledge and pedagogical content knowledge: The role of structural differences in teacher education. Journal of Teacher Education, 64(1), 90-106. doi: $10.1177 / 0022487112460398$

König, J., Lammerding, S., Nold, G., Rohde, A., Strauß, S., \& Tachtsoglou, S. (2016). Teachers' professional knowledge for teaching English as a foreign language. Journal of Teacher Education, 67(4), 320-337. doi: 10.1177/0022487116644956

Latif, E., \& Miles, S. (2011). The impact of assignments on academic performance. Journal of Economic and Economic Education Research, 12(3), 1-12.

Liakopoulou, M. (2011). The professional competence of teachers: Which qualities, attitudes, skills and knowledge contribute to a teacher's effectiveness? International Journal of Humanities \& Social Science, 1(21), 66-78.

Livingstone, C., \& Borko, H. (1989). Expert-novice differences in teaching: A cognitive analysis and implications for teacher education. Journal of Teacher Education, 36-42. doi: $10.1177 / 002248718904000407$

Mahajan, M., \& Singh, M. K. S. (2017). Importance and benefits of learning outcomes. IOSR Journal of Humanities and Social Science (IOSR-JHSS), 22(3), 65-67.

Manikowati, \& Bharati, D. A. L. (2017). The effectiveness of multimedia in teaching writing to students with different learning styles. English Education Journal, 7(2), 85-91.

Mario \& Losif (2016). Teachers' opinions concerning microteaching as a training technique: A case study from ASPETE, Greece. Journal of Education and Training Studies, 4(11), 73-78. doi: 10.11114 /jets.v4i11.1843

Mishra, P. \& Koehler, M. J. (2006). Technological pedagogical content knowledge: A framework for teacher knowledge. Teacher College Record, 108(6), 1017-1054.

Mitchell, K. M. W., \& Manzo, W. R. (2018). The purpose and perception of learning objectives. Journal of Political Science Education, 1-18. doi: 10.1080/15512169.2018.1433542

Nixon, R. S., Hill, K. M., \& Luft, J. A. (2017). Secondary science teachers' subject matter knowledge development across the first 5 years. Journal of Science Teacher Education, 28(7), 574-589. doi: 10.1080/1046560x.2017.1388086

Ogeyik, M. C. (2009). Attitudes of the student teachers in English language teaching programs towards microteaching technique. English Language Teaching, 2(3), 205-212. doi: 10.5539/ elt.v2n3p205

Onwuagboke, B. B. C., Osuala, R. C., \& Nzeako, R. C. (2017). The impact of microteaching in developing teaching skills among pre-service teachers in Alvan Ikoku college of education Owerri, Nigeria. AFRREV, African Research Review. An International Multi-Disciplinary Journal, 11(2), 237-250. doi: 10.4314/afrrev.v11i2.18

Peker, M. (2009). The use of expanded microteaching for reducing pre-service teachers' teaching anxiety about mathematics. Scientific Research and Essay, 4(9), 872-880. 
Pinter, A. 2006. Teaching young language learners. Oxford: Oxford University Press.

Poulos, A., \& Mahony, M. J. (2008). Effectiveness of feedback: The students' perspective. Assessment \& Evaluation in Higher Education, 33(2), 143-154. doi: 10.1080/02602930601127869

Punia, V., Miglani, P., \& Singh, S. P. (2016). Perception of pupil-teachers' regarding micro-teaching sessions. World Scientific News, 26, 69-77.

Rahimi, M. (2008). What do we want teaching-materials for in EFL teacher training programs? Asian EFL Journal, 31, 1-18.

Rajendra, I. M., \& Sudana, I. M. (2018). The influence of interactive multimedia technology to enhance achievement students on practice skills in mechanical technology. IOP Conference Series: Journal of Physics: Conference Series, 953, 012104. doi: 10.1088/1742-6596/953/1/012104

Reeve, J. (2009). Why teachers adopt a controlling motivating style toward students and how they can become more autonomy supportive. Educational Psychologist, 44, 159-175. doi: 10.1080/00461520903028990

Reynolds, A. (1992). What is competent beginning teaching? A review of the literature. Review of Educational Research, 62(1), 1-35. doi: 10.3102/00346543062001001

Saban, A., \& Çoklar, A. N. (2013). Pre-service teachers' opinions about microteaching method in teaching practise classes. TOJET: The Turkish Online Journal of Educational Technology, 12(2), 234-240.

Schempp, P., Tan, S., Manross, D., \& Fincher, M. (1998). Differences in novice and competent teachers' knowledge. Teachers and Teaching: Theory and Practice, 4(1), 9-20. doi: 10.1080/1354060980040102

Şen, A. İ. (2010). Effects of peer teaching and microteaching on teaching skills of pre-service physics teachers. Education and Science, 35(155), 60-88.

Seven, M. A., \& Engin, A. O. (2007). The importance and effect of using aid materials in foreign language teaching. https://files.eric.ed.gov/fulltext/ED497456.pdf

Shah, S. M. H., \& Masrur, R. (2011). Impact of microteaching skills on the performance of primary school teachers. Gomal University Journal of Research, 27(1), 15-29.

Shrout, P. E., \& Fleiss, J. L. (1979). Intraclass correlations; Uses in assessing rater reliability. Psychological Bulletin, 86(2), 420-428. doi: 10.1037/0033-2909.86.2.420

Shulman, L. S. (1986). Those who understand: knowledge growth in teaching. Educational Researcher, 15(2), 4-14.

Shulman, L. S. (1987). Knowledge and teaching: Foundations of the new reform. Harvard Educational Review, 57(1), 1-21.

Simbo, F. K. (1989). The Effects of microteaching on student teachers' performance in the actual teaching practice classroom. Educational Research, 31(3), 195-200. doi: 10.1080/0013188890310305

Skinner, E., Furrer, C., Marchand, G., \& Kindermann, T. (2008). Engagement and disaffection in the classroom: Part of a lager motivational dynamic? Journal of Educational Psychology, 100(4), 765-781. 
Spear-Swerling, L., Brucker, P. O., \& Alfano, M. P. (2005). Teachers' literacy-related knowledge and self-perceptions in relation to preparation and experience. Annals of Dyslexia, 55(2), 266-296. doi: 10.1007/s11881-005-0014-7

Suhirman, L. (2018). Lesson study-based instruction for enhancing EFL teachers' pedagogical competence. Asian EFL Journal, 20(5), 154-174.

Suryani, F. B., Rukmini, D., Bharati, D. A. L., \& Hartono, R. (2017). Enhancing EFL student teachers' teaching practice through microteaching lesson study. Asian Journal of Educational Research, 5(2), 42-49.

Tawalbeh, A., \& Al-Zuoud, K. M. (2013). The effects of students' prior knowledge of English on their writing of researches. International Journal of Linguistics, 5(3), 156-163.

Tokmak, H. S., \& Karakus, T. (2011). ICT pre-service teachers' opinions about the contribution of initial teacher training to teaching practice. Contemporary Educational Technology, 2(4), 319-332.

Tsui, A. B. M. (2009). Distinctive qualities of expert teachers. Teachers and Teaching: Theory and Practice, 15(4), 421-439. doi: 10.1080/13540600903057179

Tuan, H. L, Chang, W. H, Lee, C. K, Wang, C. Y., \& Cheng, P. Y. (2000). Developing a pedagogical content competence evaluation for apprentice physical science teachers- a case study. Proceedings of the NSC-part D: Mathematics, Science and Technology Education, 10(1), 1-14.

Uygun, T., \& Akyüz, D. (2019). Developing subject matter knowledge through argumentation. International Journal of Research in Education and Science, 5(2), 532-547.

Weinert, F. E., \& Helmke, A. (1995). Interclassroom differences in instructional quality and interindividual differences in cognitive development. Educational Psychologist, 30, 15-20. doi: 10.1207/s15326985ep3001_2

Wolff, C. E., van den Bogert, N., Jarodzka, H., \& Boshuizen, H. P. A. (2014). Keeping an eye on learning: Differences between expert and novice teachers' representations of classroom management events. Journal of Teacher Education, 66, 68-85. doi: 10.1177/0022487114549810

Yang, Y., Liu, X., \& Gardella, J. A. (2018). Effects of professional development on teacher pedagogical content knowledge, inquiry teaching practices, and student understanding of interdisciplinary science. Journal of Science Teacher Education, 1573-1847. doi: 10.1080/1046560x.2018.1439262

Yuksel, I. (2012). Activating students' prior knowledge: The core strategies. World Applied Sciences Journal, 20(8), 1197-1201. doi: 10.5829/idosi.wasj.2012.20.08.473

Zhou, G, Xu, J., \& Martinovic, D. (2017). Developing pre-service teachers' capacity in teaching science with technology through microteaching lesson study. EURASIA Journal of Mathematics Science and Technology Education, 13(1), 85-103. doi: 10.12973/eurasia.2017.00605a 


\title{
Mikromokymas vidurinio ugdymo anglų kalbos mokytojo-eksperto požiūriu: poveikis būsimujjų mokytojų pedagoginio turinio žinioms
}

\author{
Siti Aimah ${ }^{1}$, Dwi Rukmini ${ }^{2}$, Mursid Saleh ${ }^{3}$, Dwi Anggani Linggar Bharati ${ }^{4}$
}

\author{
Semarango valstybinis universitetas, Magistro programa, Jl. Kelud Utara III, Semarangas, Vidurio Java, ID-50233, \\ Indonezija, siti.aimah@unimus.ac.id \\ 2 Semarango valstybinis universitetas, Anglų kalbos ugdymo programa, Čenajus, Gunung Pati, Semarangas, \\ Vidurio Java, ID-50229, Indonezija, wiwidwirukmini@yahoo.com \\ 3 Semarango valstybinis universitetas, Anglų kalbos ugdymo programa, Čenajus, Gunung Pati, Semarangas, \\ Vidurio Java, ID-50229, Indonezija, mursids@hotmail.com \\ 4 Semarango valstybinis universitetas, Anglų kalbos ugdymo programa, Čenajus, Gunung Pati, Semarangas, \\ Vidurio Java, ID-50229, Indonezija, dwi_anggani@yahoo.com
}

\section{Santrauka}

Mokymo praktika yra baigiamoji būsimųjų anglų kalbos mokytojų praktika, kurią jie privalo atlikti, išklausę mikromokymo kursą universitete. Tačiau viena iš esminių problemų, su kuriomis susiduria būsimieji anglų kalbos mokytojai, atlikdami mokymo praktiką, yra atotrūkis tarp dèstytojų ir mokyklos mokytojų, kurie asistuoja studentams mokymo praktikos metu. Todèl, norint susieti mikromokymą ir mokymo praktiką, reikalinga vidurinio ugdymo anglų kalbos mokytojo eksperto pagalba. Šiuo tyrimu siekiama nustatyti mikromokymo poveikị būsimųjų mokytojų pedagoginio turinio žinioms, sutelkiant dèmesị ị pokyčius prieš dalyvavimą eksperto vadovaujamame mikromokyme ir po jo. Projekte dalyvavo viena grupé, kurios veikla buvo vertinta kelis kartus (tas pats laiko tarpas), o rezultatai vertinti tarp matavimų. Būsimųjų anglų kalbos mokytojų pedagoginio turinio žinios buvo ịvertintos prieš eksperto vedamą mikromokymą, jo metu ir po jo. Duomenys buvo analizuojami aprašomosios ir išvestinès statistikos metodais. Tyrimo rezultatai rodo, kad mokytojo-eksperto vedamas mikromokymas reikšmingai veikia būsimųjų anglų kalbos mokytojų pedagoginio turinio žinias ir ugdo jų gebejjimą, ko mokyti ir kaip to išmokyti, kad mokiniai suprastų. Vidurinio ugdymo anglų kalbos mokytojo-eksperto konstruktyvus grịžtamasis ryšis kartu su patarimais ir pavyzdinėmis pamokomis lemia būsimųjų anglų kalbos mokytojų pedagoginio turinio žinių pokyčius.

Esminiai žodžiai: pasikeitimai, poveikis, mokytojas-ekspertas, mikromokymas, pedagoginio turinio žinios, būsimieji anglų kalbos mokytojai. 